\title{
PASSIVE PRESSURE PULSATION DAMPING USING SHAPED NOZZLES
}

\begin{abstract}
Pressure pulsations in intake and outlet systems of positive-displacement compressors are one of the most important problems in compressed gas pipelines. This problem occurs not only in huge compressed systems, such as the natural gas piping in gas mines or national gas transport systems, but also in small refrigeration compressors in domestic applications. Nowadays systems require new approach since in all applications the variable rotational speed compressors are introduced. The mufflers designed in a conventional way on the basis of the Helmholtz theory are effective only for specific frequency range. In case of variable rotational speed the reaction of such damper may be insufficient. Therefore, any innovative ideas for pressure pulsating damping are welcomed by the compressor industry. One of the possible solutions to attenuate pressure pulsation over a wide range of frequencies is the introduction of shaped nozzles just after the compressor outlet chamber. It is obvious that the nozzle attenuates pressure pulsation, but simultaneously the requirement for the driving power of the compressor rises. The main subject of this paper is to show that using properly shaped nozzles one can achieve pressure pulsation damping, with insignificant influence on the compressor power consumption. The results of experimental investigations and some results of CFD analyses are shown in the paper, with indication for the best construction of the nozzle shape.
\end{abstract}

Key words: compressors, pressure pulsation damping, CFD simulation

\section{Introduction}

Pressure pulsations attenuation in volumetric compressors inlet and outlet systems are constantly one of the most important problems in compressed gas manifold. A pulsating gas flow significantly influences the operation of the entire compressor systems, in most cases in a negative way. Main problems being the results of pressure pulsations are piping system damages because of generated vibrations and aerodynamically generated noise. This problem occurs

${ }^{1}$ Autor do korespondencji/corresponding author: Piotr Cyklis, Politechnika Krakowska, ul. Warszawska 24, 31-155 Kraków, tel.: (+48 12) 62835 72, e-mail: pcyklis@ @ech.pk.edu.pl

${ }^{2}$ Przemysław Młynarczyk, e-mail: pmlynarczyk@pk.edu.pl 
not only in huge compressed systems, such as the natural gas piping in gas mines or national transport systems, but also in small refrigeration compressors in domestic applications. Nowadays systems require new approach since in all applications the variable rotational speed compressors are introduced. The mufflers designed in a conventional way on the basis of the Helmholtz theory have good pressure pulsations damping action only within the designed frequency range. In case of rotational speed change the reaction of the damper designed according to Helmholtz theory may be insufficient. The modelling of pressure pulsations attenuation is widely analysed in many papers dealing with problems in periodically working machines installations like compressors, pumps or engines. Various numerical methods used for calculating transmission loss in pipelines, mufflers and silencer systems are described in different studies. In [2, 7] comparison of experimental result and Helmholtz model results of pressure pulsations in existing installations are discussed. The author [2] shows that the error of conventional Helmholtz method may in some cases reach $90 \%$ and after introducing a new transmittance matrix method significant improvements have been achieved. The same method has been applied by the authors $[3,5,6]$ to model and analyse different acoustic systems. Most of the articles which are not involved in the experiment are generally about pulsation and vibration control philosophies. Authors generally describe sources of problems and examples of actual solving methods of these problems. Even though this article is about the pulsations caused by the compressors and pipelines vibrations there is also a lot of interesting articles treating about a car mufflers vibrations as, for instance in $[1,8]$. The article [4] describes interesting algorithm for the efficient acoustic analysis of silencers of any general geometry with transfer matrix analysis. There is several interesting works about CFD. Paper [9] describes a CFD simulation of single pipe excited with a single disturbance. Response, which is periodic with a constant frequency is characterized by a certain degree of damping. Experimental investigations and CFD analysis of a nozzle pressesured pulsating flow is the core of this paper.

\section{Laboratory test stand}

All experimental measurements of the pressure pulsations have been performed in the DEMAG screw compressor outflow pipe. The passive choking elements mounted in the compressor manifold have been investigated as pulsation attenuators. The test stand is presented in the figure 1 . 


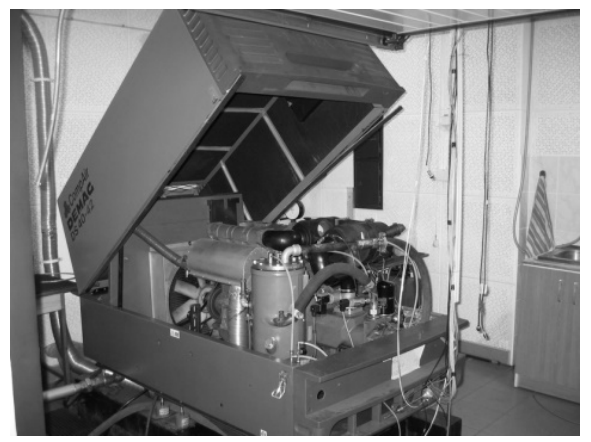

Fig. 1. The test stand - a mobile DEMAG DS-40 CompAir unit

\subsection{Measurement system}

The place of assembly of the investigated elements is located $17 \mathrm{~mm}$ above the compressor discharge chamber. The pressure pulsations have been measured using PCB Piezotronics ICP Dynamic Pressure Sensors. The signal from sensors goes through the 4-channel ICP Sensor Line Power unit and to the NI USB-6251 data acquisition module as well as to the computer with LabView data acquisition. The scheme of the measuring system is shown in the figure 2 .

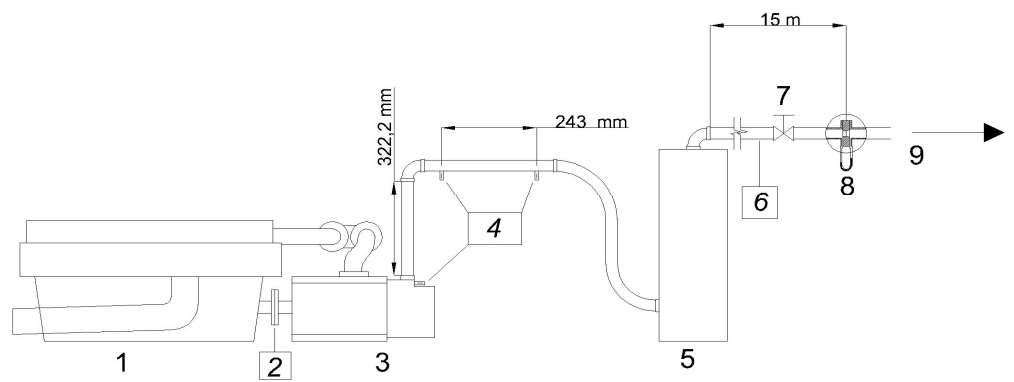

Fig. 2. Measuring system, where: 1- engine, 2- torque meter on the propeller shaft, 3- screw compressor, 4- pressure pulsations sensors, 5- oil Separator, 6- static pressure transducer, 7- throttle valve, 8- measuring orifice, 9- outflow

After the equilibrium state of the compressor has been reached, the parameters: pressure and temperature for various components of the system, power, torque and rotational speed, and ambient conditions have been recorded. The volume flow rate has been determined using the accurate metering orifice.

\subsection{Investigated muffling elements}

The possibility of pressure pulsations passive damping, using specially shaped nozzle placed in the gas duct flow directly after the compressor outlet chamber has been analysed. Arbitrary chosen nozzle shapes have been prepared for experimental analysis of the pressure pulsations damping. In the fig. 3 ex- 
amples of nozzles geometries are shown - there are three main nozzle profiles in different configurations and size. The shapes of Venturi orifice, Venturi nozzle and hyperboloidal nozzle have been chosen as most promising for pressure attenuation with low flow restriction. Every shape was investigated in three different dimensions of the inner flow diameter which was: $\varphi 10, \varphi 15$ and $\varphi 20$. Some chosen shapes are used in measurements in both directions and in configuration of two elements joined together. The key element of this investigation is the assessment of the nozzle influence on the pulsation on the basis of computer simulation. The method has been proposed by Cyklis [3]. Each element may be characterised by its transmittance. Transmittance describes the response of the element to flow excitation for upward and downward flow.

a)

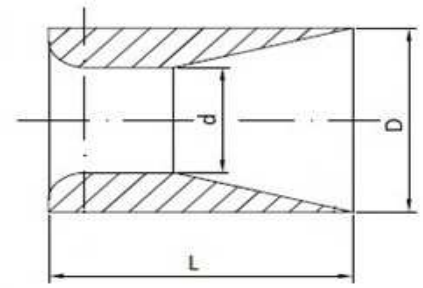

b)

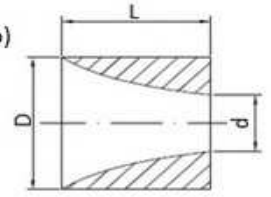

c)

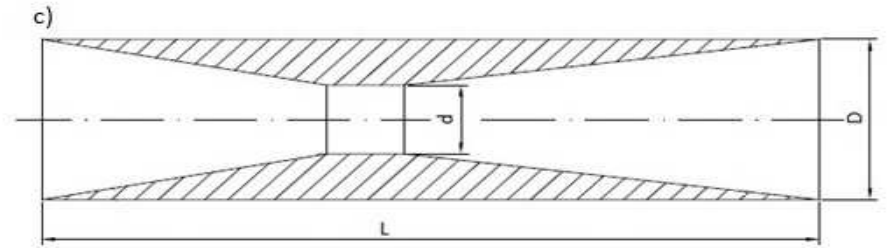

Fig. 3. Shape and main dimensions of the: a) Venturi nozzle,

b) Hyperboloidal nozzle, c) Venturi orifice

In case of a manifold element there are two physical phenomena: pressure and flow pulsations which may be used in calculation as excitation or response. There are two ways to calculate transmittances: experimental [2] or theoretical based on the CFD simulation [3]. The concept of the method is as follows: for a considered element of a manifold a full multi-dimensional CFD non-linear simulation is carried out, solving the Navier-Stokes set of equations numerically together with the necessary closing models, i.e. gas state model, turbulence model, boundary conditions. The results obtained are averaged at the inlet and outlet of the element in question, and then a complex transformation of the results is performed, so that the transmittances consistent with the generalized form of matrices are calculated. In this way the advantages of both methods can be combined: the Helmholtz model possibility of analysis of geometrically complex installations and the possibility of introducing real geometry of any element, without a priori simplifications. The pipe outlet as closed end or an open for CFD simulation boundary condition has been applied. On the basis of 
the CFD simulation with impulse flow excitation the nozzle element influence on the pressure pulsations have been analysed.

\section{Simulation and experimental results compare}

For CFD simulations the FLUENT software has been used. Simulation conditions were 2D axisymmetric, ideal gas isentropic flow model with applied Reynolds stress turbulence model. The model mesh contains three boundary layers at wall and consists of two areas with different element size.

Boundary conditions:

- At the inlet impulse excitation of the $0.1[\mathrm{~kg} / \mathrm{s}]$ value. The impulse excitation means that its duration is equal to one time step,

- Pressure outlet where the pressure at the outlet is defined as arithmetical average between pressure outside domain and the last cell inside the domain,

- Wall (also for closed end elements) where tangential stresses are included in the momentum conservation equation.

Then the results have been spatially averaged at the inlet and outlet to obtain one dimensional flow and pressure pulsations, being the result of the impulse flow excitation. The damping coefficient $\xi$, the free frequency $\omega$, delay time $\Delta \tau$, and amplification coefficient $\mathrm{K}$ can be estimated analysing pulsation curves. The problem requires decomposition of the function for each free frequency. The method assumes linearity as the concept of transmittance requires. However the linearization is used on the "a posteriori" simulation results, and CFD simulation is not linear in general.

In the figure 4 the absolute damping coefficient $\xi$ values for different nozzle shapes are shown.

\section{Absolute damping coefficient value}

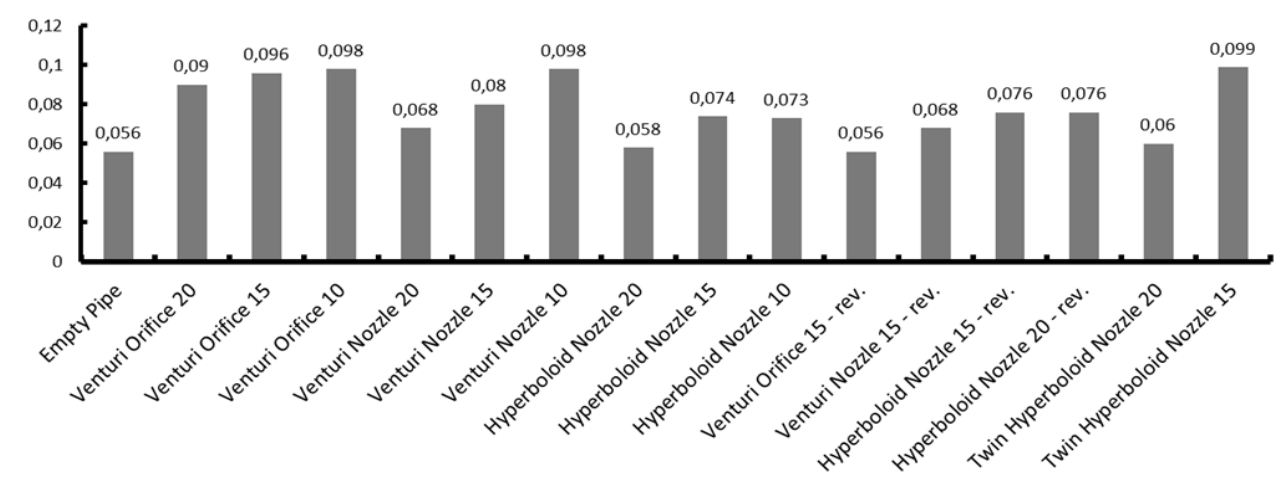

Fig. 4. The comparison of absolute damping coefficient values for different nozzle shapes 
The basic experimental results show the comparison graphs for peak to peak damping characteristics for different types of elements. In the figure 5 results for compressor rotational speed at the level of 1650 [rpm]are presented.

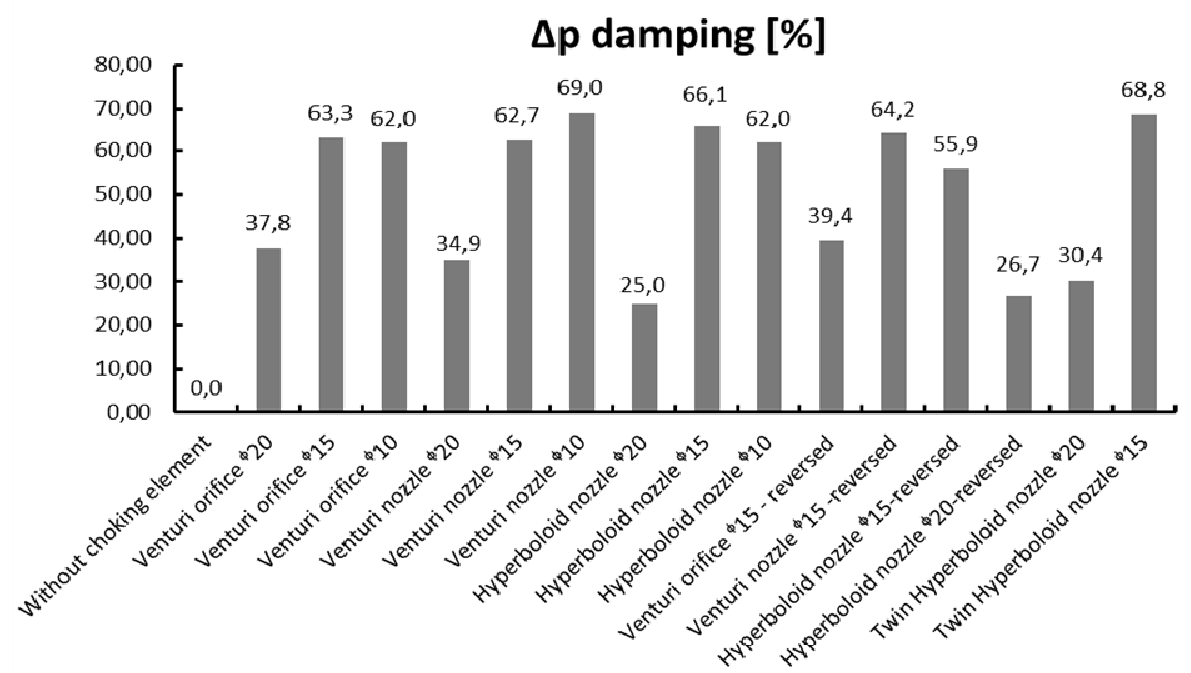

Fig. 5. Peak-to-peak damping for $1615[\mathrm{rpm}]$ referring to empty pipe

The presented graphs show that there is a correlation between CFD simulations and experimental investigations. It is obvious that obtained in simulations damping coefficient values are not proportional to experimental peak-to-peak damping because of, for example, simplified geometry. In simulations there is only pipe with choking element and in the experiment the final pressure pulsations value is influenced by many other factors like valves operation, pipe bends, additional elements in system (like oil separator) and more. However, when comparing different groups of shapes can be seen that relations between pulsation damping gained from experiment and damping coefficient calculated in the simulation for shapes with considered diameters are similar.

\section{Conclusions}

The innovative method for attenuation of the pressure pulsations in volumetric compressor manifold has been presented. The proposed solution is to apply the specially shaped nozzles, which will attenuate pulsations with low influence on the compressor required power. The advantage of the proposed solution is that it works for wide range of rotational speed of the compressor. The disadvantage is that for one frequency of pressure pulsation the nozzle will have usually lower attenuation capabilities than the Helmholtz 
theory based volumetric muffler. There is also an issue with the influence on the compression required power. Therefore the optimization of shape and dimension is required. One of the tools for the shape and dimension choice is the CFD simulation. Classic simulation would require simulation for all frequencies. In this paper the simulation of the impulse excitation on the pipe inlet has been applied. This allows to have more general solution for all range of frequencies. The results of this simulation are similar to the experimental results. This means that this method of the simulation may be used for shape and dimension optimization.

\section{References}

[1] Andersen K.S.: Analyzing muffler performance using the transfer matrix method, COMSOL Conf., Hannover 2008.

[2] Cyklis P.: Experimental identification of the transmittance matrix for any element of the pulsating gaz manifold, J. Sound Vibration, 244 (2001) 859-870.

[3] Cyklis P.: Transmittance estimation for any element of volumetric compressor manifold using CFD simulation, Arch. Mech. Eng., 56 (2009) 157-171.

[4] Dowling J.F., Peat K.S.: An algorithm for the efficient acoustic analysis of silencers of any general geometry, Appl. Acoustics, 65 (2003) 211-227.

[5] Georges S.N.Y., Jordan R., Thieme F.A., Bento Coelho J.L., Arenas J.P.: Muffler modeling by transfer matrix method and experimental verification, ABCM, XXVII (2005) 132-140.

[6] Huang Z., Jian W.: Vibration analysis of pipelines with arbitrary branches by absorbing transfer matrix method, J. Sound Vibration, 306 (2007) 215-226.

[7] Ma Y.-C. and Min O.-K..: Pressure calculation in a compressor cylinder by a modified new Helmholtz modeling, J. Sound Vibration, 243 (2001)775-796.

[8] Mehidizadeh O.Z., Paraschivoiu.: A three-dimensional finite element approach for predicting the transmission loss in mufflers and silencers with no mean flow, Appl. Acoustics, 66 (2005) 902-918.

[9] Sekavcnik M., Ogorevc T., Skerget L.: CFD analysis of the dynamic behaviour of a pipe system, Forsh Ingenieurwes, 70 (2006) 139-144.

\section{PASYWNE TŁUMIENIE PULSACJI CIŚNIENIA RÓŻNOKSZTAŁTNYMI DYSZAMI}

\section{Streszczenie}

Pulsacje ciśnienia w układach wlotowych i wylotowych sprężarek wyporowych są jednym z największych problemów obecnych w rurociągach sprężonego gazu. Problem ten występuje nie tylko $\mathrm{w}$ wielkich układach sprężających, jak rurociągi tłoczne gazu ziemnego w kopalniach gazu lub państwowych systemach transportu gazu, ale również przy codziennym użytkowaniu małych sprężarek chłodniczych. Obecnie wymagane jest nowe podejście do tego typu systemów wynikające z coraz większego zastosowania sprężarek o zmiennej 
prędkości obrotowej. Tłumiki projektowane w konwencjonalny sposób, na bazie teorii Helmholtza, są skuteczne tylko dla konkretnego zakresu częstotliwości. W przypadku sprężarek o zmiennej prędkości obrotowej działanie takiego tłumika może być niewystarczające. Przemysł sprężarkowy jest więc nastawiony na innowacyjne pomysły z zakresu tłumienia pulsacji ciśnienia. Jednym z możliwych rozwiązań tłumienia pulsacji ciśnienia w szerokim zakresie częstotliwości jest wprowadzenie specjalnie ukształtowanych dysz bezpośrednio za komorą wylotową sprężarki. Oczywistym jest tłumienie pulsacji ciśnienia przez dyszę $\mathrm{w}$ wyniku rozpraszania energii jednakże zarazem wzrasta zapotrzebowanie sprężarki na moc napędową. Tematem niniejszego artykułu jest wykazane, że przy użyciu odpowiednio ukształtowanych dysz można osiągnąć tłumienie pulsacji ciśnienia zarazem nie zwiększając stanowczo poboru mocy. Wyniki badań eksperymentalnych oraz kilka wyników analiz CFD przedstawiono w artykule, ze wskazaniem na kilka najlepszych rozwiązań kształtu dyszy.

Keywords: sprężarki, tłumienie pulsacji ciśnienia, symulacje CFD

DOI: $10.7862 / \mathrm{rm} .2014 .35$

Otrzymano/received: 25.05 .2014

Zaakceptowano/accepted: 28.06 .2014 